\title{
ANALISIS PERBEDAAN KUALITAS PELAYANAN LEMBAGA KEUANGAN MIKRO KSP. MUGI LESTARI SYARIAH DENGAN BMT MARDHATILLAH BERKAH
}

\author{
Enjang Suherman, SE.,MM \\ enjangsuherman@ubpkarawang.ac.id
}

\begin{abstract}
The purpose of research analyze the difference of service quality KSP. Mugi Lestari Syariah with BMT Mardhatillah Berkah. The operations of both financial institutions, that the customers to decrease. Beside that, KSP. Mugi Lestari Syariah and BMT Mardhatillah Berkah are members of the Mugi Lestari Group forum.

The Mugi Lestari Group has made improvements in the management of its members. Especially KSP. Mugi Lestari Syariah and BMT Mardhatillah Berkah. Handling in improving the quality of service can be done with the same or different depending on the characteristics of both financial institutions. Therefore, Required research to know there is difference or equality in service quality, KSP. Mugi Lestari Syariah with BMT. Mardhatillah Berkah.

This research method using comparative study with quantitative descriptive approach verifikatif. This research not only knows the similarity or difference of service quality of both institutions. But can also find out descriptively how the service quality of each financial institution.

The results showed that there wasn't a difference in service quality, KSP. Mugi Lestari Syariah with BMT Mardhatillah Berkah. Using different test Independent Sample T-test found that t arithmetic 0,594 <than t table 1,97 with $d f(1)$ with error rate $0,05 \%$. While descriptive analysis of service quality KSP. Mugi Lestari on good criteria with score value 494,5 and descriptive analysis of service quality BMT Mardhatillah Berkah on good criteria with score value 552,5.
\end{abstract}

Key: Sevice Quality

\section{PENDAHULUAN}

Salah satu faktor terpenting dalam usaha koperasi adalah kemampuan dalam memberikan pelayanan yang baik. Kualiatas pelayan diperlukan untuk mempertahankan kelangsungan hidup dan dapat memberikan kepuasan kepada anggotanya. Dalam hal memberikan pelayanan prima Parasuraman memberikan beberapa dimensi pelayanan yang perlu dilakukan oleh lembaga keuangan meliputi:

1. Tangibles, atau bukti fisik yaitu kemampuan suatu koperasi dalam menunjukkan penampilannya pada pihak eksternal.

2. Reliability, atau keandalan yaitu kemampuan koperasi untuk memberikan pelayanan sesuai yang dijanjikan secara akurat dan terpercaya.

3. Responsiveness, atau ketanggapan yaitu suatu kemauan pegawai koperasi untuk membantu dan memberikan pelayanan yang cepat (responsive) dan tepat kepada anggota..

4. Assurance, atau jaminan dan kepastian yaitu jaminan kebijakan yang konsisten, kesopan santunan, dan kemampuan para pegawai koperasi untuk menumbuhkan rasa percaya pelanggan kepada lembaga. 
5. Empathy, yaitu memberikan perhatian yang tulus dan bersifat individual atau pribadi yang diberikan kepada anggota dengan berupaya memahami keinginan anggota dimana suatu lembaga keuangan.

Koperasi Simpan Pinjam (KSP) Mugi Lestari Syariah merupakan salah satu koperasi yang bergerak dalam bidang keuangan yang melayani simpanan dan pinjaman kepada anggotanya. KSP. Mugi Lestari Syariah berdiri di Karawang dengan badan hukum koperasi akan tetapi dalam anggaran rumah tangganya menganut sistem syariah.

Baitul Maal Wa Tamwil (BMT) Mardhatillah Berkah merupakan lembaga keuangan mikro yang berbasis syariah dengan badan hukum koperasi simpan pinjam, dimana dalam Anggaran rumah tangganya menganut sistem syariah. Kegiatan Baitul tamwil adalah mengembangkan usaha-usaha produktif dan investasi dalam meningkatkan kualitas kegiatan ekonomi pengusaha kecil dengan antara lain mendorong kegiatan menabung dan menunjang kegiatan ekonominya. Sedangkan Kegiatan Baitul Maal adalah menerima titipan BAZIS dari dana zakat, infaq dan sadaqah dan menjalankannya sesuai dengan peraturan dan amanahnya.

KSP. Mugi Lestari Syariah pada tahun 2016 memiliki anggota koperasi sebanyak 603 pada bulan Oktober 2016. Sedangkan BMT Mardhatillah Berkah pada tahun 2016 memiliki anggota koperasi sebanyak 669 orang pada bulan Oktober 2016. Pada perkembangannya dari tahun ke tahun jumlah anggota cenderung menurun, hal tersebut terindikasi atas kepuasan anggota atas pelayanan yang dilakukan koperasi cenderung menurun. Oleh sebab itu diperlukan penyelidikan dalam bentuk penelitian atas kualitas pelayanan tersebut.

Kedua lembaga keuangan tersebut termasuk dalam forum Mugi Lestari Group. Dimana Mugi Lestari Group terdiri dari beberapa badan usaha yang dikelola bersama-sama oleh salah satu pengurus. Mugi Lestari Group akan melakukan perbaikan atas pengelolaan badan usahanya terutama lembaga keuangan mikro yaitu KSP. Mugi Lestari Syariah dan BMT Mardhatillah Berkah. Ketika kualitas pelayanan kedua lembaga keuangan tersebut sama, maka penanganan yang akan dilakukan sama, begitu juga sebaliknya ketika kualitas pelayanan kedua lembaga keuangan tersebut berbeda maka perbaikan pelayanan tersebut akan berbeda. Oleh sebab itu diperlukan analisis perbedanaan antara kedua lembaga keuangan yaitu KSP. Mugi Lestari Syariah dengan BMT Mardhatillah Berkah.

\section{RUMUSAN MASALAH}

Berdasarkan latar belakang tersebut maka penulis membatasi masalah dengan merumuskan berbagai rumusan masalah yaitu:

1. Bagaimana kualitas pelayanan KSP. Mugi Lestari Syariah? 
2. Bagaimana kualitas pelayanan BMT. Mardhatillah Berkah?

3. Apakah terdapat perbedaan kualitas pelayanan KSP. Mugi Lestari Syariah dengan BMT Mardhatillah Berkah?

\section{TUJUAN PENELITIAN}

Tujuan penelitian ini diharapkan dapat menjawab rumusan masalah yang telah dipertanyakan rumusan masalah yaitu:

1. Menganalisis kualitas pelayanan KSP. Mugi Lestari Syariah.

2. Menganalisis kualitas pelayanan BMT Mardhatillah Berkah

3. Menganalisis perbedaan kualitas pelayanan KSP. Mugi Lestari Syariah dengan BMT Mardhatillah Berkah.

\section{LANDASAN TEORI}

\section{Kualitas Pelayanan}

Supranto (2011) kualitas adalah sebuah kata yang bagi penyedia jasa merupakan sesuatu yang harus dikerjakan dengan baik. Aplikasi kualitas sebagai sifat dari penampilan produk atau kinerja merpakan bagian utama strategi perusahaan dalam rangka meraih keunggulan yang berkesinambungan, baik sebagai pemimpin pasar ataupun strategi untuk terus tumbuh.

Menurut Wyckof (dalam Fandy Tjiptono, 2004:59), kualitas layanan adalah tingkat keunggulan yang diharapkan dan pengendalian atas tingkat keunggulan tersebut untuk memenuhi keinginan pelanggan.

Ada dua faktor yang mempengaruhi kualitas jasa, yaitu expected service dan perceived service (Fandy Tjiptono 2004:60). Dengan demikian, tingginya tingkat kualitas layanan dapat diukur dengan membandingkan antara expected service dengan perceived service.

Terdapat lima determinasi kualitas jasa yang dapat dirinci sebagai berikut (Philip Kotler 1994:561).

a. Keandala: kemampuan untuk melaksanakan jasa yang dijanjikan dengan tepat dan terpercaya. Seperti kemudahan dalam transaksi, keseriuasan dalam memproses pembiayaan dan lainnya.

b. Keresponsifan: kemauan untuk membantu pelanggan dan memberikan jasa dengan cepat atau tanggap. Seperti kemampuan koperasi menanggapi masalah yang timbul, kecepatan pegawai dalam transaksi, dan kemampuan komunikasi yang baik dengan anggota. 
c. Keyakinan: pengetahuan dan kesopanan karyawan serta kemampuan mereka untuk menimbulkan kepercayaan dan keyakinan. Seperti keramahan pegawai melayani nasabah, kejujuran karyawan dalam transaksi dan lain sebagainya.

d. Empati: syarat untuk peduli, memberi perhatian pribadi bagi karyawan. Seperti memberikan perhatian kepada anggota, pelayanan yang adil terhadap semua anggota dan lain sebagainya.

e. Berwujud: penampilan fasilitas fisik, peralatan, personel dan media komunikasi. Seperti kerapihan dan kebersihan pegawai koperasi dalam melayani, peralatan transaksi pegawai tertata dengan baik dan sebagainya.

\section{Koperasi}

Koperasi merupakan organisasi otonom dari orang-orang yang berhimpun secara sukarela untuk memenuhi kebutuhan dan aspirasi ekonomi, sosial dan budaya secara bersama-sama melalui kegiatan usaha yang dimiliki dan dikendalikan secara demokratis. Dengan demikian koperasi memiliki jati diri dari, oleh dan untuk anggota serta dalam menjalankan kegiatannya berpedoman pada prinsip-prinsip koperasi. (Hendar:2010)

Menurut Alma (2015) Usaha koperasi disusun oleh anggota dan untuk anggota. Pimpinan dalam Koperasi disebut pengurus yang dipilih oleh anggota dalam masa jabatan tertentu. Dikatakan bahwa koperasi tumbuh dari golongan lemah, bersatu guna memenuhi kebutuhan bersama. Usaha koperasi lebih banyak bersifat sosial menolong anggota dari pada motif yang mencari keuntungan sebesar-besarnya.

Suhendi dan Sasangka (2014) menyebutkan terdapat lima jenis-jenis koperasi yaitu: (1) koperasi simpan pinjam; (2) koperasi konsumen; (3) koperasi produsen; (4) koperasi pemasaran; (5) koperasi jasa.

Koperasi merupakan suatu kumpulan dari orang-orang yang mempunyai tujuan atau kepentingan bersama. Pembentukan koperasi berdasarkan asas kekeluargaan dan gotong royong khusus untuk membantu para anggotanya yang memerlukan bantuan baik berbentuk pinjaman uang atau barang. Koperasi simpan pinjam adalah usaha pembiayaan, yaitu menghimpun dana dari para anggotanya yang kemudian menyalurkan kembali dana tersebut kepada para anggotanya atau memasyarakatkan umum. (Kasmir: 2012).

Menurut Zimmerer (2002) terdapat lima sumber penting dalam mengembangkan daya saing yaitu: (a) Fokus pada anggota; (b) Kesetiaan pada kualitas pelayanan; (c) Perhatikan atas kenyamanan; (d) Mengembangkan inovasi; (e) Dedikasi pada pelayanan.

\section{BMT}


Menurut Djazuli (2002) Baitul Mal Wa Tamwil (BMT) adalah balai usaha mandiri terpadu yang isinya berintikan bayt al-mal wa at-tamwil dengan kegiatan mengembangkan usahausaha produktif dan investasi dalam meningkatkan kualitas kegiatan ekonomi pengusaha kecil bawah dan kecil dengan mendorong kegiatan menabung dan menunjang pembiayaan kegiatan ekonominya. Selain itu, BMT juga dapat meneruma titipan infak, zakat dan sedekah serta penyalurannya sesuai dengan peaturan dan amanatnya. BMT merupakan lembaga ekonomi atau lembaga keuangan syariah nonperbankan yang bersifat informal atau formal.

Menurut Azis dalam Imayanti (2010) BMT adalah balai usaha yang dikembangkan dari konsep baitul maal wat tamwil. Dari segi baitul maal, BMT menerima titipan bazis dari dana zakat, infak dan sedekah memanfaatkannya untu kesejahteraan masyarakat kecil, fakir, miskin. Pada aspek baitul tamwil, BMT mengembangkan usaha-usaha produktif untuk meningkatkan pendapatan pengusaha kecil dan anggota.

Menurut Imyanti (2010) kegiatan yang dikembangkan BMT adalah:

1. Menggalang dan menghimpun dana yang dipergunakan untuk membiayai usaha-usaha anggotanya. Modal awal BMT diperoleh dari simpanan pokok khusus para pendiri. Selanjutnya, BMT mengembangkan modalnya dari simpanan pokok, simpanan wajib, dan simpanan sukarela anggota.

2. Memberikan pembiayaan kepada anggota sesuai dengan penilaian kelayakan yang dilakukan oleh pengelola BMT bersama anggota yang bersangkutan. Sebagai imbalan atas jasa ini, BMT akan mendapat bagi hasil sesuai aturan yang ada.

3. Mengelola usaha simpan pinjam itu secara profesional sehingga kegiatan BMT bisa menghasilkan keuntungan dan dapat dipertanggung jawabkan.

Mengembangkan usaha-usaha di sektor riil yang bertujuan untuk mencari keuntungan dan menunjang usaha anggota. Misalnya distribusi dan pemasaran; penyediaan bahan baku dan lain-lain.

Aziz (2004) mengemukakan tujuan BMT meliputi terciptanya sistem lembaga dan kondisi kehidupan ekonomi rakyat banyak dilandasi oleh nilai-nilai dasar salam (keselamatan) berintikan keadilan, kedamaian, dan kesejahtraan, melandasi tumbuh dan berkembangnya tiga perempat usaha mikro dan kecil di seluruh Indonesia.

\section{KERANGKA BERFIKIR}

Kualiatas pelayanan yang dilakukan oleh kedua lembaga keuanga tersebut KSP. Mugi Lestari Syariah dan BMT Mardhatillah Berkah dapat ditingkatkan sesuai dengan kebutuhan dan keinginan anggota. KSP. Mugi Lestari Syariah dan BMT Mardhatillah Berkah termasuk 
dalam anggota forum Mugi Lestari Group dimana seluruh anggota Mugi Lestari Group ingin memperbaiki seluruh kegiatan kualitas pelayanan bagi seluruh anggotanya terutama lembaga keuangan syariah. Oleh sebab itu perlu dilakukan analisis perbandingan kualitas pelayanan tersebut agar dalam perbaikan kualitas pelayanan sama atau tidak.

Beberapa penelitian telah dilakukan dalam analisis perbandingan kualitas pelayanan baik secara metode kualitatif maupun kuantitatif termasuk penelitian yang dilakukan Indah Komalasari Siregar (2013) tentang Studi Komparatif Peran Koperasi Simpan Pinjam Bina Bersama Dan BMT Insani Dalam Pengembangan Umk Di Kota Padangsidimpuan. Hasil penelitian tersebut yaitu Berdasarkan Uji U test, dapat hasil untuk omset dan modal pinjaman menunjukan terdapat perbedaan anatara koperasi simpan pinjam Bina Bersama dengan Koperasi BMT Insani.

Berdasarkan kerangka pemikiran tersebut maka peneliti mengajukan sebuah model penelitian dalam melatarbelakangi kerangka pemekiran tersebut atas studi komparatif analisis perbedaan kualitas pelayanan lembaga keuangan mikro KSP. Mugi Lestari Syariah dengan BMT Mardhatillah Berkah.

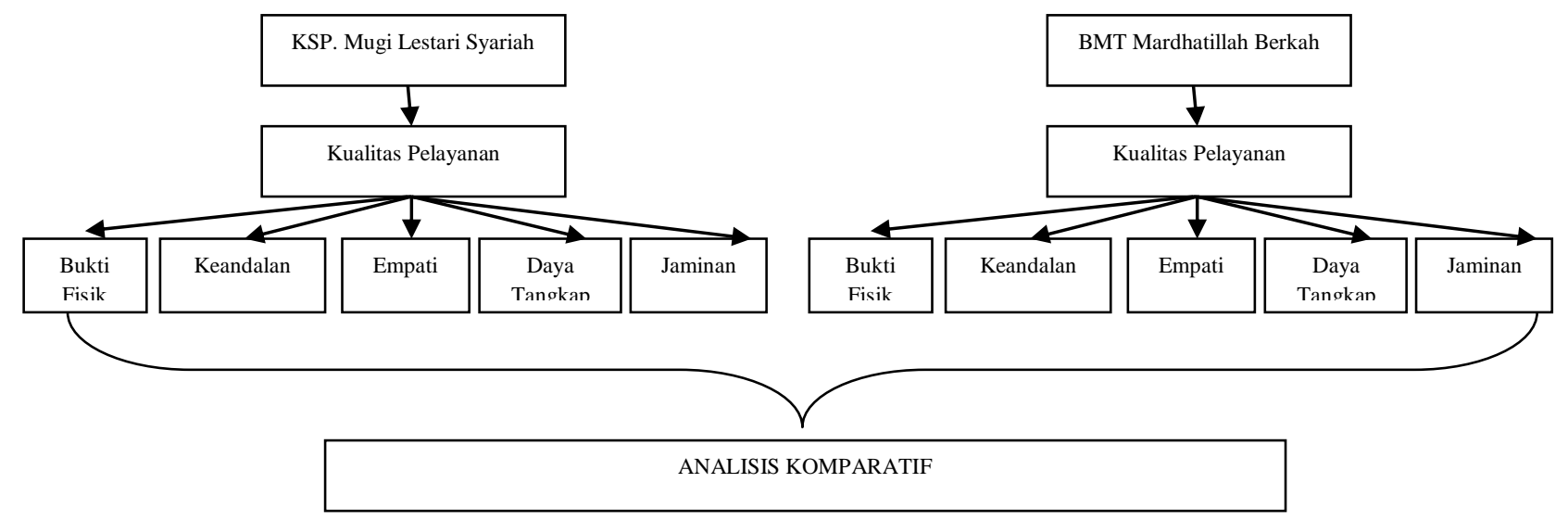

Gambar 2.2 Kerangka Berfikir Analisis Komparatif

\section{DESAIN PENELITIAN}

Penelitian ini menggunakan metodologi pendekatan kuantitaif deskriptif verifikatif. yaitu untuk menganalisis perbedaan kualitas pelayanan lembaga keuangan mikro KSP. Mugi Lestari Syariah dengan BMT Mardhatillah Berkah.

\section{VARIABEL}

Kualitas pelayanan merupakan upaya pada pemenuhan kebutuhan dan keinginan anggota. Dalam upaya memenuhi kebutuhan anggota maka diperlukan beberapa indikator pelayanan tersebut antara lain: 
Tabel 4.1 Operasionalisasi Variabel

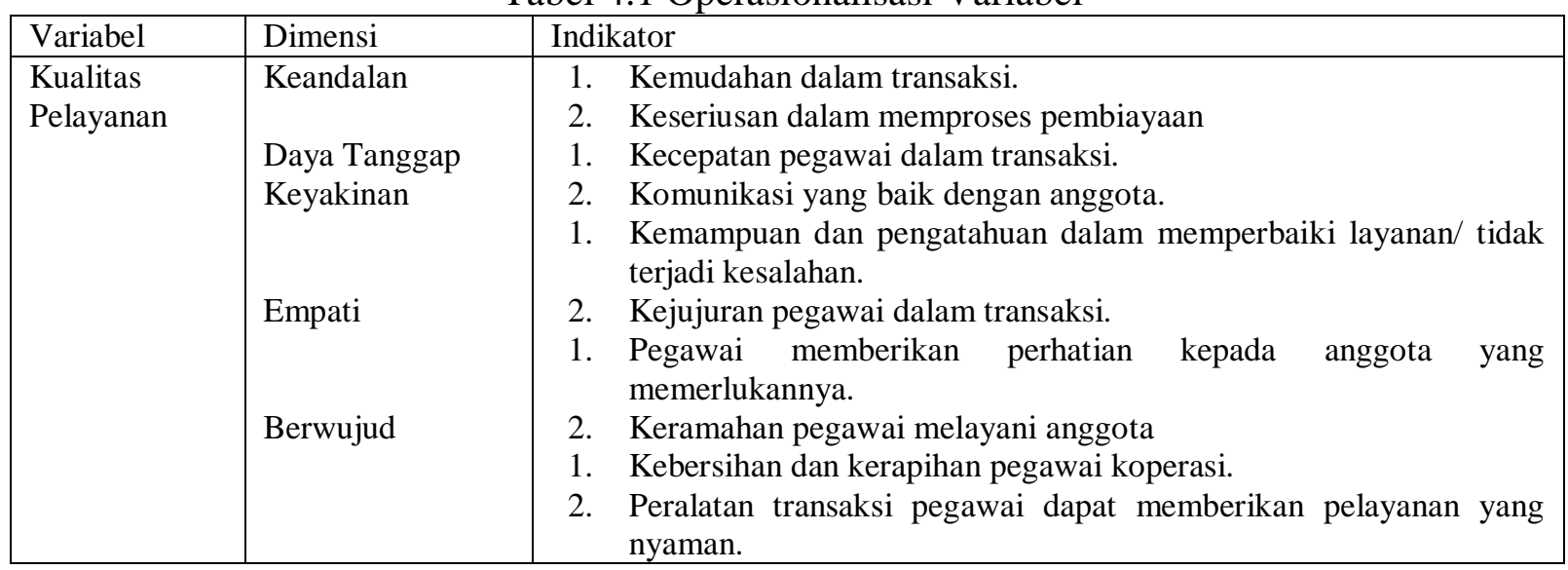

Sumber: Olah data 2017

\section{MODEL YANG DIGUNAKAN}

Modal yang digunakan dalam penelitian ini adalah sebagai berikut:

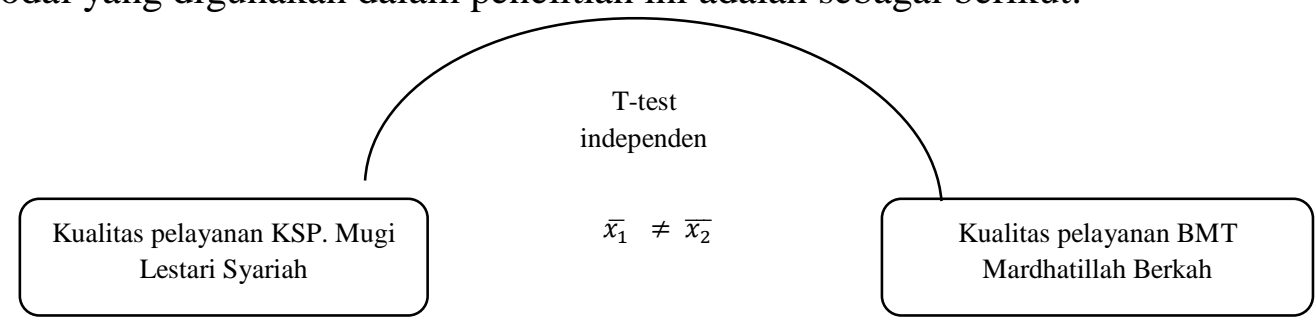

Gambar 4.1

Model Penelitian

\section{TEKNIK PENGUMPULAN DATA}

\section{Populasi}

Yang menjadi populasi penelitian ini adalah seluruh anggota KSP. Mugi Lestari Syariah berjumlah 603 orang dan anggota BMT Mardhatillah Berkah berjumlah 669 orang.

2. Sampel

Data dikumpulkan dengan mengambil sampel secara random sampling yang ditentukan dengan menggunakan mengambil sampel 20\% dari populasi untuk KSP. Mugi Lestari Syariah dan mengambil 20\% dari populasi untuk BMT Mardhatillah Berkah maka didapat sampel untuk 120 responden untuk KSP. Mugi Lestari Syariah dan sampel 133 responden untuk BMT Mardhatillah Berkah. Sedangkan teknik pengumpulan data menggunakan teknik angket dan wawancara terbatas untuk memperoleh informasi tertentu.

Dalam hal ini, menggunakan skala likert terdiri dari penilaian kualitas pelayanan untuk masing-masing lembaga yaitu: 
Penilaian kualitas pelayan tersebut diberikan bobot sebagai berikut: (a) Jawaban sangat baik diberi bobot 5; (b) Jawaban baik diberi bobot 4; (c) Jawaban cukup baik diberi bobot 3; (d) Jawaban kurang baik diberi bobot 2; (d) Jawaban tidak baik diberi bobot 1

\section{TEKNIK ANALISIS}

1. Uji keabsahan data

Uji keabsahan data menggunakan uji validitas dan reliabilitas yaitu dengan menggunakan analisis corrected item-Total Correlation dan Croanbach's Alpha (SPSS). Validitas $\mathrm{r}$ hitung > 0,3 (Instrument Valid) ; Reliabilitas Croanbach's Alpha > 0,6. (Instrumen Reliabel)

\section{Uji Prasyarat Komparatif}

Uji prasyarat menggunakan uji normalitas dan homogenitas, adapun analisisnya yaitu:

a. Uji Normalitas menggunakan uji kolmogorov-smirnov dengan menggunakan SPSS.

Uji Normalitas Sig. Hitung > 0,05 berdistribusi normal

b. Uji Homogenitas menggunakan uji Bartlet.

Langkah-langkahnya:

1). Varian gabungan Dari sampel $\mathrm{s}^{2}=\frac{\sum d k s_{1}^{2}}{\sum d k}$

2). $B=\left(\sum d k\right) \log s^{2} ;$ Sehingga nilai $\chi^{2}=(\ln 10)\left\{\mathrm{B}-\Sigma(\mathrm{dk}) \log \mathrm{S}_{\mathrm{k}}^{2}\right\}$

Jika nilai $\alpha=0,05$, dari daftar distribusi chi square dengan dk didapat jika $\chi^{2}$ hitung $<\chi_{\text {tabel }}^{2}=$ Ho diterima atau data tersebut homogen.

3. Analisis Deskriptif

Menggunakan rentang skala dan dibuat matriks mana saja yang baik dan tidak baik serta buat penjelasan yang detail. Tidak menggunakan angka rata-rata tapi boleh menggunakan modus dan median karena datanya ordinal.

\section{a. Rentang Skala}

Cara menentukan rentang skala dengan menggunakan rumus sebagai berikut:

$\mathrm{RS}=\frac{n(m-1)}{m}$

Dimana :

$\mathrm{n}=$ jumlah $; \mathrm{m}=$ jumlah alternative jawaban tiap item

rentang skala KSP. $=\frac{120(5-1)}{5}=96$; rentang skala BMT $\frac{133(5-1)}{5}=106$

Skala rendah $=$ skor rendah $\mathrm{x}$ jumlah sampel

Skala rendah KSP $=1 \mathrm{x} 120=120 \quad$ Skala rendah BMT $=1 \mathrm{x} 133=133$

Skala tertinggi $=$ Skor tertinggi $\mathrm{x}$ jumlah sampel 
Skala tertinggi $\mathrm{KSP}=5 \mathrm{x} 120=600 \quad$ Skala tertinggi $\mathrm{BMT}=5 \mathrm{x} 133=665$

Tabel 4.2 Kreteria Dalam Rentang Skala

\begin{tabular}{|c|c|c|l|}
\hline Skala skor & Rentang Skala KSP & Rentang Skala BMT & \multicolumn{1}{|c|}{ Kriteria } \\
\hline 1 & $120-215$ & $133-238$ & Tidak baik \\
\hline 2 & $216-311$ & $239-344$ & Kurang Baik \\
\hline 3 & $312-407$ & $345-450$ & Cukup baik \\
\hline 4 & $408-503$ & $451-556$ & Baik \\
\hline 5 & $503-600$ & $557-665$ & Sangat baik \\
\hline
\end{tabular}

Sumber : Diolah (2017)

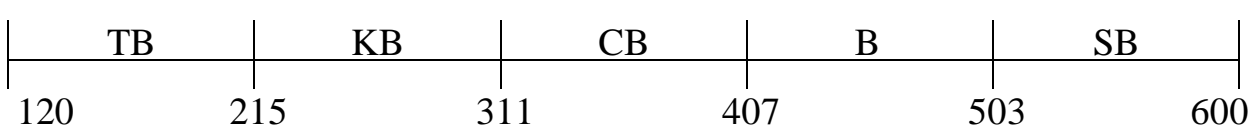

Gambar 4.3 Bar Scale KSP. Mugi Lestari Syariah

\begin{tabular}{|c|c|c|c|c|c|}
\hline & & & & & \\
\hline 133 & 238 & 344 & 450 & 556 & 665 \\
\hline
\end{tabular}

Gambar 4.4 Bar Scale BMT Mardhatillah Berkah

\section{Analisis Verifikatif}

Uji Independent Sample T-test merupakan bagian dari statistik inferensial parametetrik (uji beda). Statistik parametrik terdapat syarat-syarat yang harus dipenuhi sebelum dilakukan pengujian. Syarat tersebut yaiti data berdistribusi normal dan data harus homogen. Dengan menggunakan rumus:

Cari standar deviasi gabungan

$$
S^{2} g b=\frac{(n 1-1) S_{1}^{2}+(n 2-1) S_{2}^{2}}{n 1+n 2-2} ; \text { Uji t yaitu } t=\frac{\overline{X_{1}}-\overline{X_{2}}}{\sqrt{S^{2} g b\left(\frac{1}{n_{1}}+\frac{1}{n_{2}}\right)}}
$$

$\mathrm{H} 0$ diterima jika $\mathrm{t}$ hitung $<\mathrm{t}$ tabel $; \mathrm{H} 1$ diterima jika $\mathrm{t}$ hitung $>\mathrm{t}$ tabel

\section{ANALISIS DATA}

\section{Deskripsi Data}

Berdasarkan hasil penelitian maka didapat data responden KSP. Mugi Lestari Syariah dan BMT Mardhatillah Berkah sebagai berikut:

Tabel 5.1 Data Responden

\begin{tabular}{|c|c|c|c|c|}
\hline No & Lembaga & Jumlah Laki-laki & Jumlah Perempuan & Total \\
\hline 1 & KSP. Mugi Lestari Syariah & 50 & 70 & 120 \\
\hline 2 & BMT Mardhatillah Berkah & 53 & 80 & 133 \\
\hline & Jumlah & 103 & 150 & 253 \\
\hline
\end{tabular}

Sumber: data olah 2017

Data Responden KSP. Mugi Lestari Syariah jumlah laki-laki sebesar 50 orang sedangkan jumlah perempuan sebesar 70 orang. Adapun data responden BMT Mardhatillah Berkah jumlah laki-laki sebesar 53 orang sedangkan jumlah perempuan sebesar 80 orang. 
Berdasarkan data tersebut mayoritas anggota masing-masing lembaga tersebut di dominasi anggota perempuan dari pada laki-laki. Hal ini menunjukan perempuan lebih aktif dalam simpan pinjam di koperasi dari pada laki-laki.

\section{Uji Keabsahan Data}

Hasil data yang diperoleh perlu di uji keabsahan data sebelum proses analisis deskriptif dan analisis verifikatif. Dalam uji keabsahan data meliputi uji validitas, uji reliabilias, uji homogenitas, dan uji normalitas. Proses uji kebasahan data menggunaka softwere SPSS dalam perhitungannya.

Tabel 5.2 Uji Validitas data KSP. Mugi Lestari Syariah

\begin{tabular}{|l|r|r|r|r|}
\hline \multicolumn{7}{|c|}{ Item-Total Statistics } \\
\hline & $\begin{array}{c}\text { Scale Mean if } \\
\text { Item Deleted }\end{array}$ & $\begin{array}{c}\text { Scale Variance if } \\
\text { Item Deleted }\end{array}$ & $\begin{array}{c}\text { Corrected Item-Total } \\
\text { Correlation }\end{array}$ & $\begin{array}{c}\text { Cronbach's Alpha } \\
\text { if Item Deleted }\end{array}$ \\
\hline item 1 & 37,05 & 18,01429 & 0,508597 & 0,843693 \\
\hline item 2 & 37,10833 & 17,92934 & 0,545272 & 0,840493 \\
\hline item 3 & 37,16667 & 18,03922 & 0,492613 & 0,845182 \\
\hline item 4 & 36,85833 & 18,17304 & 0,567192 & 0,839106 \\
\hline
\end{tabular}

Sumber: Data Olah SPSS 2017

Tabel 5.2 Uji Validitas data KSP. Mugi Lestari Syariah (Lanjutan)

\begin{tabular}{|l|r|r|r|r|}
\hline \multicolumn{7}{|c|}{} & $\begin{array}{c}\text { Item-Total Statistics } \\
\text { Item Deleted }\end{array}$ & $\begin{array}{c}\text { Scale Variance if } \\
\text { Item Deleted }\end{array}$ & $\begin{array}{c}\text { Corrected Item-Total } \\
\text { Correlation }\end{array}$ & $\begin{array}{c}\text { Cronbach's Alpha } \\
\text { if Item Deleted }\end{array}$ \\
\hline item 5 & 37,11667 & 17,83501 & 0,55569 & 0,839593 \\
\hline item 6 & 36,93333 & 17,50812 & 0,597125 & 0,835903 \\
\hline item 7 & 37,11667 & 17,58291 & 0,602918 & 0,835501 \\
\hline item 8 & 36,925 & 17,09517 & 0,685075 & 0,828085 \\
\hline item 9 & 36,98333 & 17,62997 & 0,536384 & 0,841493 \\
\hline item 10 & 37,39167 & 17,8369 & 0,487912 & 0,846156 \\
\hline
\end{tabular}

Sumber: Data Olah SPSS 2017

Berdasarkan uji validitas tabel 5.2 data KSP. Mugi Lestari Syariah untuk semua item pernyataan valid, hal ini dapat dilihat pada Corrected Item-Total Correlation semua data lebih besar dari pada 0,3 sebagai angka kritis.

Tabel 5.3 Uji Validitas data BMT Mardhatillah Berkah

\begin{tabular}{|c|c|c|c|c|}
\hline \multicolumn{5}{|c|}{ Item-Total Statistics } \\
\hline & $\begin{array}{l}\text { Scale Mean if } \\
\text { Item Deleted }\end{array}$ & $\begin{array}{c}\text { Scale Variance if } \\
\text { Item Deleted }\end{array}$ & $\begin{array}{l}\text { Corrected Item- } \\
\text { Total Correlation }\end{array}$ & $\begin{array}{l}\text { Cronbach's Alpha } \\
\text { if Item Deleted }\end{array}$ \\
\hline item 1 & 37,30827 & 15,83607 & 0,527797 & 0,810093 \\
\hline item 2 & 37,49624 & 15,05491 & 0,513848 & 0,811205 \\
\hline item 3 & 37,51128 & 15,46389 & 0,4562 & 0,817333 \\
\hline item 4 & 37,15038 & 15,94691 & 0,449506 & 0,817008 \\
\hline item 5 & 37,43609 & 15,18717 & 0,588349 & 0,803364 \\
\hline
\end{tabular}




\begin{tabular}{|l|r|r|r|r|} 
item 6 & 37,23308 & 15,64981 & 0,562248 & 0,80691 \\
\hline item 7 & 37,36842 & 15,38596 & 0,566199 & 0,805804 \\
\hline item 8 & 37,21053 & 15,54625 & 0,452497 & 0,81752 \\
\hline item 9 & 37,22556 & 14,97904 & 0,622549 & 0,799733 \\
\hline item 10 & 37,72932 & 15,6383 & 0,428059 & 0,820281 \\
\hline
\end{tabular}

Sumber: Data Olah SPSS 2017

Berdasarkan uji validitas tabel 5.3 data BMT Mardhatillah Berkah untuk semua item pernyataan valid, hal ini dapat dilihat pada Corrected Item-Total Correlation semua data lebih besar dari pada 0,3 sebagai angka kritis.

Tabel 5.4 Uji Reliabilitas data KSP. Mugi Lestari Syariah dan KSP. BMT Mardhatillah Berkah Reliability Statistics

Cronbach's Alpha KSP. Mugi Lestari Syariah Cronbach's Alpha BMT Mardhatillah Berkah 0,853276 0,826625

Sumber: Data Olah SPSS 2017

Uji reliabilitas data KSP. Mugi Lestari Syariah sebesar 0,853 sedangkan data BMT Mardhatillah Berkah sebesar 0,826. Ini menunjukan bahwa uji reliabilitas semua data reliabel karena data tersebut lebih besar dari 0,6 sebagai angka kritisnya.

Tabel 5.5 Uji normalitas data KSP. Mugi Lestari Syariah dan KSP. BMT Mardhatillah Berkah

\begin{tabular}{|l|l|r|}
\hline \multicolumn{2}{|c|}{ One-Sample Kolmogorov-Smirnov Test } \\
\hline N & & \multicolumn{1}{|c|}{ Unstandardized Residual } \\
\hline Normal Parametersa & Mean & $5,79814 \mathrm{E}-15$ \\
\hline & Std. Deviation & 4,640820904 \\
\hline Most Extreme Differences & Absolute & 0,064548009 \\
\hline & Positive & 0,063107074 \\
\hline & Negative & $-0,064548009$ \\
\hline Kolmogorov-Smirnov Z & & 0,707088012 \\
\hline Asymp. Sig. (2-tailed) & & 0,699405598 \\
\hline a. Test distribution is Normal. & & \\
\hline
\end{tabular}

Sumber: Data Olah 2017

Berdasarkan uji normalitas menggunakan uji kolmogorov-smirnov dengan menggunakan SPSS. Didapatkan sig hitung 0,699 lebih besar dari pada sig 0,05, hal ini menunjukan bahwa data tersebut berdistribusi normal.

Tabel 5.6 Uji homogenitas data KSP. Mugi Lestari Syariah dan KSP. BMT Mardhatillah Berkah

\begin{tabular}{|c|c|c|c|c|c|c|}
\hline Sampel & DK & $1 / \mathrm{DK}$ & $\mathrm{S}_{\mathrm{i}}{ }^{2}$ & $\log \mathrm{S}_{\mathrm{i}}{ }^{2}$ & $\mathrm{dk} \log \mathrm{S}_{\mathrm{i}}{ }^{2}$ & $\sum \mathrm{dkS}_{\mathrm{i}}{ }^{2}$ \\
\hline Koperasi & 119 & 0,0084 & 21,580 & 1,334 & 158,751 & 2567,967 \\
\hline BMT & 132 & 0,0076 & 18,736 & 1,273 & 167,995 & 2473,203 \\
\hline Jumlah & 251 & & & & 326,746 & 5041,170 \\
\hline
\end{tabular}




\begin{tabular}{|c|c|c|}
\hline$S^{2}(\mathrm{gab})$ & $\sum \mathrm{dkS}_{\mathrm{i}}^{2} / \mathrm{DK}$ & 20,084 \\
\hline \multicolumn{2}{|c|}{$\log \mathrm{S}^{2}$} & 1,302857594 \\
\hline$B$ & $\left(\sum \mathrm{dk}\right) \log \mathrm{S}^{2}$ & 327,017256 \\
\hline \multicolumn{2}{|c|}{$\ln 10$} & 2,302585093 \\
\hline \multicolumn{2}{|c|}{$\mathrm{B}-\Sigma(\mathrm{dk}) \log \mathrm{Si}^{2}$} & 0,272 \\
\hline \multicolumn{2}{|c|}{$\chi^{2}=(\ln 10)\left\{\mathrm{B}-\Sigma(\mathrm{dk}) \log \mathrm{S}_{\mathrm{k}}{ }^{2}\right\}$} & 0,625561097 \\
\hline \multicolumn{2}{|c|}{$\chi^{2}$ tabel df1 } & 3,84 \\
\hline
\end{tabular}

\section{Sumber: Data Olah 2017}

Pada tabel 5.6 uji homogenitas didapatkan $\chi^{2}$ hitung yaitu 0,625 lebih besar dari $\chi^{2}$ tabel dengan df $(1 ; 0,05)$ yaitu 3,84 . Berdasarkan data tersebut $\chi^{2}$ hitung $<\chi^{2}$ tabel maka data uji homogenitas memiliki kesamaan atau homogen.

\section{Analisis Deskriptif}

Rekapitulasi data KSP. Mugi Lestari Syariah dapat di uraikan sebagai berikut:

Tabel 5.7 Rekapitulasi Data KSP. Mugi Lestari Syariah

\begin{tabular}{|c|c|c|c|c|c|c|c|c|c|c|c|}
\hline & Tingkatan & $\begin{array}{c}\text { Kemudahan } \\
\text { transaksi }\end{array}$ & $\begin{array}{l}\text { Keseriusan } \\
\text { memproses }\end{array}$ & $\begin{array}{c}\text { Kecepatan } \\
\text { transaksi }\end{array}$ & $\begin{array}{l}\text { Komunikasi } \\
\text { baik }\end{array}$ & $\begin{array}{l}\text { Kemampuan } \\
\text { memperbaiki }\end{array}$ & $\begin{array}{c}\text { Kejujuran } \\
\text { transaksi }\end{array}$ & Perhatian & $\begin{array}{c}\text { Keramahan } \\
\text { pegawai }\end{array}$ & $\begin{array}{c}\text { Penampilan } \\
\text { pegawai }\end{array}$ & $\begin{array}{l}\text { Peralatan } \\
\text { transaksi }\end{array}$ \\
\hline 1 & Tidak Baik & 0 & 0 & 0 & 0 & 0 & 0 & 0 & 0 & 0 & 0 \\
\hline 2 & Kurang Baik & 0 & 2 & 0 & 0 & 0 & 0 & 0 & 0 & 0 & 2 \\
\hline 3 & Cukup Baik & 23 & 18 & 30 & 10 & 25 & 19 & 25 & 18 & 24 & 44 \\
\hline 4 & Baik & 58 & 69 & 58 & 61 & 62 & 52 & 62 & 53 & 48 & 51 \\
\hline 5 & Sangat Baik & 39 & 31 & 32 & 49 & 33 & 49 & 33 & 49 & 48 & 23 \\
\hline
\end{tabular}

Sumber: Data Olah 2017

Tabel 5.8 Rekapitulasi Skor Data KSP. Mugi Lestari Syariah

\begin{tabular}{|c|c|c|c|c|c|c|c|}
\hline Indikator & Tidak Baik & Kurang Baik & Cukup Baik & Baik & Sangat Baik & Jumlah & Kriteria \\
\hline Kemudahan transaksi & 0 & 0 & 23 & 58 & 39 & & \multirow{2}{*}{ Baik } \\
\hline Skor & 0 & 0 & 69 & 232 & 195 & 496 & \\
\hline Keseriusan memproses pembiayaan & 0 & 2 & 18 & 69 & 31 & & \multirow{2}{*}{ Baik } \\
\hline Skor & 0 & 4 & 54 & 276 & 155 & 489 & \\
\hline Kecepatan transaksi pegawai & 0 & 0 & 30 & 58 & 32 & & \multirow{2}{*}{ Baik } \\
\hline Skor & 0 & 0 & 90 & 232 & 160 & 482 & \\
\hline Komunikasi baik & 0 & 0 & 10 & 61 & 49 & & \multirow{2}{*}{ Sangat Baik } \\
\hline Skor & 0 & 0 & 30 & 244 & 245 & 519 & \\
\hline Kemampuan memperbaiki layanan & 0 & 0 & 25 & 62 & 33 & & \multirow{2}{*}{ Baik } \\
\hline Skor & 0 & 0 & 75 & 248 & 165 & 488 & \\
\hline Kejujuran transaksi pegawai & 0 & 0 & 19 & 52 & 49 & & \multirow{2}{*}{ Sangat Baik } \\
\hline Skor & 0 & 0 & 57 & 208 & 245 & 510 & \\
\hline Perhatian kepada anggota & 0 & 0 & 25 & 62 & 33 & & \multirow{2}{*}{ Baik } \\
\hline Skor & 0 & 0 & 75 & 248 & 165 & 488 & \\
\hline Keramahan pegawai & 0 & 0 & 18 & 53 & 49 & & \multirow{2}{*}{ Sangat Baik } \\
\hline Skor & 0 & 0 & 54 & 212 & 245 & 511 & \\
\hline Penampilan pegawai & 0 & 0 & 24 & 48 & 48 & & Sangat Baik \\
\hline
\end{tabular}




\begin{tabular}{|c|c|c|c|c|c|c|c|}
\hline \hline Skor & 0 & 0 & 72 & 192 & 240 & 504 & \\
\hline Peralatan transaksi & 0 & 2 & 44 & 51 & 23 & \\
\hline Skor & 0 & 4 & 132 & 204 & 115 & 455 & Baik \\
\hline \multicolumn{2}{|c|}{ Skor Total } \\
\hline
\end{tabular}

Sumber: Data Olah 2017

Rekapitulasi data KSP. Mugi Lestari Syariah menunjukan bahwa untuk setiap item indikator menunjukan pada posisi baik, hal ini dapat dilihat pada data modus pada tingkatan baik. Sedangkan rekapitulasi skor data pada tabel 5.8 menunjukan pada kriteria baik dengan skor total 494,2. Dengan demikian dibuatkan Bar Scale pada gambar 5.1 sebagai berikut.

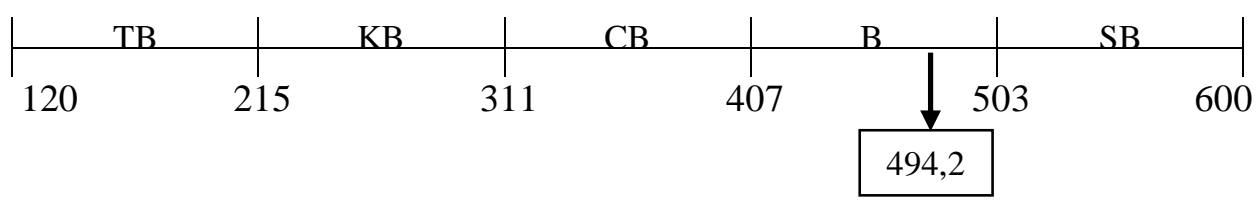

Gambar 5.1 Hasil Bar Scale KSP. Mugi Lestari Syariah

Rekapitulasi data BMT Mardhatillah Berkah dapat di uraikan sebagai berikut:

Tabel 5.9 Rekapitulasi Data BMT Mardhatillah Berkah

\begin{tabular}{|c|l|c|c|c|c|c|c|c|c|c|c|}
\hline \multicolumn{2}{|c|}{} & Tingkatan & $\begin{array}{c}\text { Kemudahan } \\
\text { transaksi }\end{array}$ & $\begin{array}{c}\text { Keseriusan } \\
\text { memproses } \\
\text { pembiayaan }\end{array}$ & $\begin{array}{c}\text { Kecepatan } \\
\text { transaksi } \\
\text { pegawai }\end{array}$ & $\begin{array}{c}\text { Komunikasi } \\
\text { baik }\end{array}$ & $\begin{array}{c}\text { Kemampuan } \\
\text { memperbaiki } \\
\text { layanan }\end{array}$ & $\begin{array}{c}\text { Kejujuran } \\
\text { transaksi } \\
\text { pegawai }\end{array}$ & $\begin{array}{c}\text { Perhatian } \\
\text { kepada } \\
\text { anggota }\end{array}$ & $\begin{array}{c}\text { Keramahan } \\
\text { pegawai }\end{array}$ & $\begin{array}{c}\text { Penampilan } \\
\text { pegawai }\end{array}$ \\
\hline 1 & Tidak Baik & 0 & 0 & 0 & 0 & 0 & 0 & 0 & 0 & 0 & 0 \\
\hline 2 & Kurang Baik & 0 & 2 & 0 & 2 & 0 & 0 & 0 & 4 & 0 & 2 \\
\hline 3 & Cukup Baik & 13 & 32 & 37 & 7 & 25 & 11 & 20 & 10 & 17 & 48 \\
\hline 4 & Baik & 79 & 60 & 58 & 64 & 72 & 73 & 73 & 60 & 60 & 59 \\
\hline 5 & Sangat Baik & 41 & 39 & 38 & 60 & 36 & 49 & 40 & 59 & 56 & 24 \\
\hline
\end{tabular}

Sumber: Data Olah 2017

Rekapitulasi data BMT Mardhatillah Berkah menunjukan bahwa untuk setiap item indikator menunjukan pada posisi baik, hal ini dapat dilihat pada data modus pada tingkatan baik pada tabel 5.9 .

Begitu pula dengan skor rekapitulasi data BMT Mardhatillah Berkah merupakan perkalian item skor dengan tingkatan skor data sehingga menunjukan kriteria setiap pelayanan yang diberikan oleh BMT Mardhatillah Berkah. Berdasarkan hasil analisis, maka di dapat simpulkan bahwa skor data BMT Mardhatillah Berkah berkriteria baik. Hal ini dapat dilihat pada tabel 5.10 dengan skor total 552,2. Sedangkan bar scale dilihat pada gamber 5.2 
Tabel 5.10 Rekapitulasi Skor Data BMT Mardhatillah Berkah

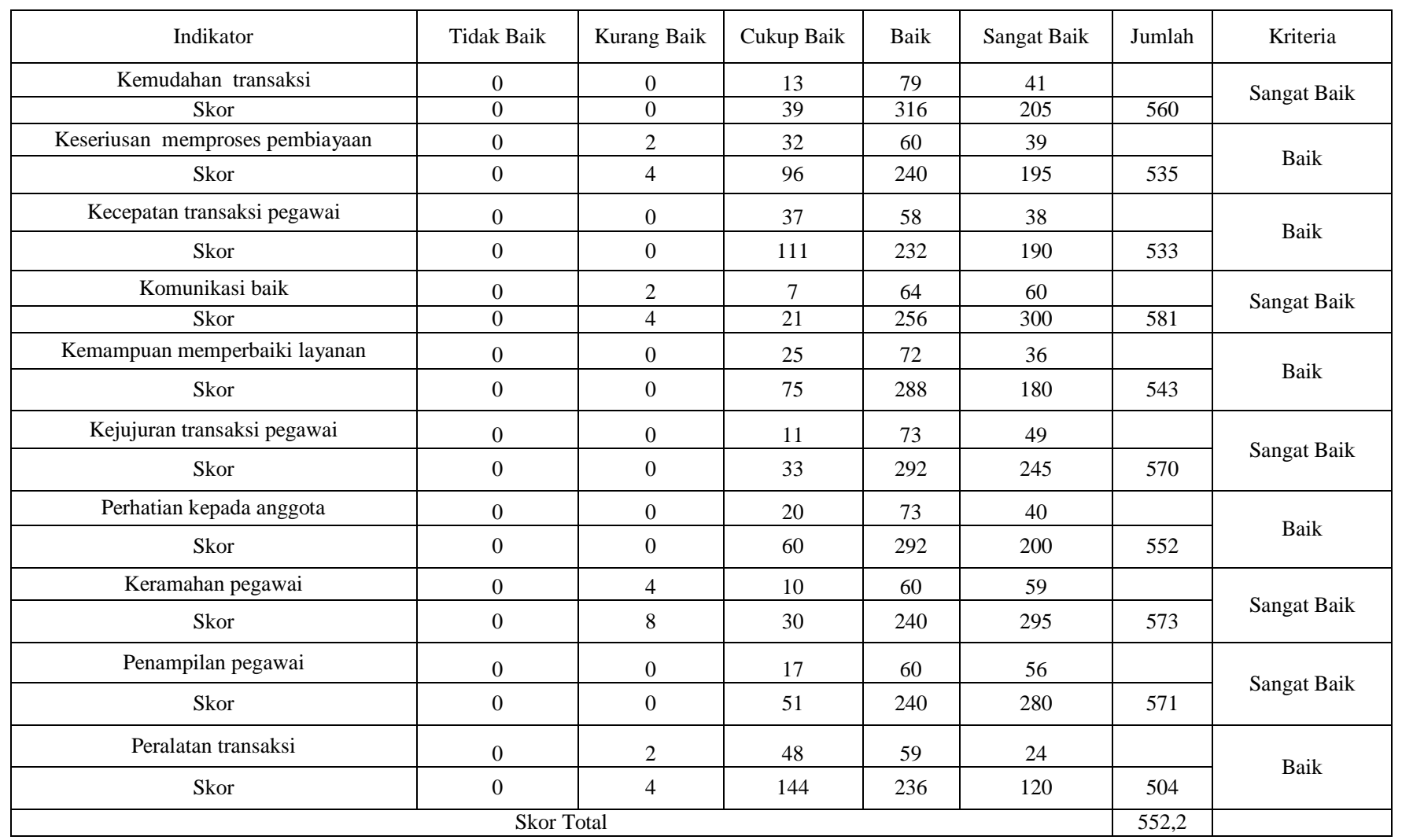

Sumber: Data Olah 2017

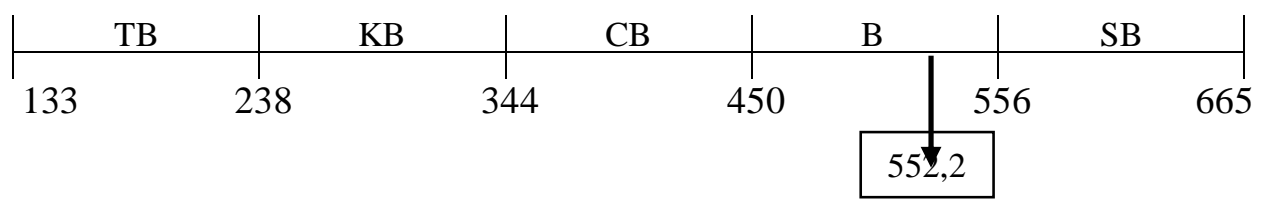

Gambar 5.2 Hasil Bar Scale BMT Mardhatillah Berkah

\section{Analisis Verifikatif}

Uji Independent Sample T-test merupakan bagian dari statistik inferensial parametetrik (uji beda). Analisis data yang digunakan adalah Uji Independent Sample T-test dengan rumus sebagai berikut:

Cari standar deviasi gabungan

$$
S^{2} g b=\frac{(n 1-1) S_{1}^{2}+(n 2-1) S_{2}^{2}}{n 1+n 2-2}
$$

Uji t yaitu $t=\frac{\overline{X_{1}}-\overline{X_{2}}}{\sqrt{S^{2} g b\left(\frac{1}{n_{1}}+\frac{1}{n_{2}}\right)}}$

$\mathrm{H} 0$ diterima jika $\mathrm{t}$ hitung $<\mathrm{t}$ tabel

$\mathrm{H} 1$ diterima jika $\mathrm{t}$ hitung $>\mathrm{t}$ tabel 
Tabel 5.11 Analisis data Verifikatif

\begin{tabular}{|c|c|c|c|c|c|c|}
\hline$\overline{X_{1}}$ & $\overline{X_{2}}$ & $S_{1}^{2}$ & $S_{2}^{2}$ & $n 1$ & $n 2$ & t tabel \\
\hline 41,2 & 41,5 & 21,6 & 18,7 & 120 & 133 & 1,97 \\
\hline
\end{tabular}

Sumber: Olah data 2017

$$
\begin{gathered}
S^{2} g b=\frac{(120-1) 21,6+(133-1) 18,7}{120+133-2}=20,084 \\
t=\frac{41,2-41,5}{\sqrt{20,084\left(\frac{1}{120}+\frac{1}{133}\right)}}=0,594
\end{gathered}
$$

Berdasarkan hasil perhitungan uji Independent Sample T-test di dapatkan bahwa $\mathrm{t}$ hitung 0,594 < daripada t tabel 1,97 dengan df (1) dengan tingkat kesalahan 0,05\%. Dengan demikian bahwa Ho diterima yaitu tidak terdapat perbedaan antara kualitas pelayanan KSP. Mugi Lestari dengan BMT Mardhatillah Berkah.

\section{PEMBAHASAN}

\section{Pembahasan Deskriftif}

Analissi deskriftif didapatkan bahwa kualitas pelayanan KSP. Mugi Lestari Syariah pada kriteria Baik hal ini didapat dilihat hasil skor total pada nilai 494,2. Sedangkan terdapat beberapa item yang dinilai kurang optimal dengan skor nilai terendah yaitu

1. Peralatan pelayanan transaksi dengan skor nilai 455 dengan kriteria baik. Walaupun skor tersebut tinggi akan tetapi masih dinilia kurang optimal yang diterima oleh anggota. Alat-alat yang digunakan oleh KSP, Mgi lestari syariah masih tergolong semi modern dan perlu melek teknologi.

2. Perhatian kepada anggota dengan skor nilai 488 dengan kriteria baik. Petugas koperasi masih dianggap acuh untuk sebagian anggota. Tapi kebanyakan mengangggap sudah pada kreteria baik.

Analissi deskriftif kualitas pelayanan BMT Mardhatillah Berkah pada kriteria Baik hal ini didapat dilihat hasil skor total pada nilai 552,2. Sedangkan terdapat beberapa item yang dinilai kurang optimal dengan skor nilai terendah yaitu

1. Peralatan pelayanan transaksi dengan skor nilai 504 dengan kriteria baik. Walaupun skor tersebut tinggi akan tetapi masih dinilia kurang optimal yang diterima oleh anggota. Alat-alat yang digunakan oleh BMT Mardhatillah Berkah masih tergolong semi modern dan perlu melek teknologi. 
2. Perhatian kepada anggota dengan skor nilai 552 dengan kriteria baik. Petugas BMT masih dianggap acuh untuk sebagian anggota. Tapi kebanyakan mengangggap sudah pada kreteria baik.

Berdasarkan analisis deskriftif hampir memiliki kesamaan dalam kualitas pelayanan, akan tetapi masih terdapat beberapa perbedaan yang perlu dibuktikan dengan menggunakan analisis verifikatif.

\section{Pembahasan Verifikatif}

Uji verifikatif menggunakan uji beda yaitu Independent Sample T-test. Uji beda ini memverifikasi apakah terdapat perbedaan atau persamaan antara dua variabel yang homogen yaitu data KSP. Mugi Lestari Syariah dengan data BMT Mardhatillah Berkah.

Berdasarkan hasil analisis didapatkan bahwa uji Independent Sample T-test didapatkan Ho diterima yaitu tidak terdapat perbedaan atara kualitas pelayanan KSP, Mugi Lestari Syariah dengan kualitas pelayanan BMT Mardhatillah Berkah. Hal ini dibuktikan dengan t hitung 0,594 < daripada t tabel 1,97 dengan df (1) dengan tingkat kesalahan 0,05\%.

Dengan demikian dapat disimpulkan penelitian ini bahwa walaupun KSP. Mugi Lestari Syariah kualitas pelayanan homogen dengan BMT Mardhatillah Berkah masih tidak ada perbedaan yang signifikan dengan melihat $t$ hitung < dari pada t tabel. Sehingga untuk perbaikan pelayanan kualitas pelayanan dapat menggunakan beberapa metode yang sama berdasarkan sifat dan kualitas pelayanan yang diberikan.

\section{KESIMPULAN}

Bedasarkan hasil analisis dan pembahasan maka dapat disimpulkan penelitian ini sebagai berikut:

1. Kualitas pelayanan KSP. Mugi Lestari Syariah pada kriteria baik hal ini dapat dilihat dari persepsi anggota dengan skor total nilai 494,2. Namun demikian perlu perbaikan untuk menjadi sangat baik.

2. Kualitas pelayanan BMT Mardhatillah Berkah pada kriteria baik hal ini dapat dilihat dari persepsi anggota dengan skor total nilai 552,2. Namun demikian perlu perbaikan untuk menjadi sangat baik.

3. Uji Verifikatif yang telah dilakukan menunjukan bahwa tidak terdapat perbedaan kualitas pelayanan KSP. Mugi Lestari Syariah dengan kualitas pelayanan BMT Mardhatillah 
Berkah dengan melihat bahwa t hitung 0,594 < daripada t tabel 1,97 dengan df (1) dengan tingkat kesalahan $0,05 \%$ maka Ho terima.

\section{DAFTAR PUSTAKA}

A. Dazuli. 2002. Lembaga Perekonomian Umat. Jakarta: Raja Grafindo Persada.

Alma, Buchari. 2015. Pengantar Bisnis. Bandung: Alfabeta.

Arikunto, Suharsimi. 2006. Prosedur Penelitian Suatu Pendekata Praktik, Jakarta: Rineka cipta

Aziz, M. Amin. 2004. Pedoman Pendirian BMT (Baitul Maal wat Tamwil). Jakarta: Pinbuk Press.

Christyanto Sahoa. 2013. Analisis Perbandingan Kualitas Pelayanan antara organisasi swasta dengan organisasi publik (suatu studi di CV. Nasional Motor Kota Manado dan Dinas Kependudukan dan Pencatatan Sipil Kota Manado). Manado: Universitas Sam Ratulanggi. Jurnal Governance vol 5 No. 1.

Hendar. 2010. Manajemen Perusahaan Koperasi Pokok-pokok pikiran mengenai Manajemen dan Kewirausahaan Koperasi. Jakarta: Erlangga.

Imaniyati, Neni Sri. 2010. Aspek-Aspek Hukum BMT (Baitul Maal wat Tamwil). Bandung: Citra Aditya Bakti.

Ridwan, Ahmad Hasan. 2013. Manajemen Baitul Mal watamwil. Bandung. Pustaka Setia.

Janwari, Yadi. 2000. Lembaga-lembaga Perekonomian Syariah. Bandung: Pustaka Mulia.

J. Supranto. 2011. Pengukuran tingkat kepuasan pelanggan. Jakarta: Rineka Cipta

Kasmir. 2012. Bank dan lembaga keuangan lainnya. Jakarta: Rajagrafindo pers

Kotler, Philip. 1994. Marketing Manajemen:Analisys, Planning, Implementation \& Control. Prentice Hall International Editions: Eighth Edition

Nursan Nugroho, Ema Utami, Maha Taufiq. 2013. Analisis Perbandingan Kualitas Pelayanan Penerimaan Mahasiswa Baru Z(PMB) Online Menggunakan Model Kesuksesan Sistem Informasi Delone dan MC Lean (D\&M) (studi kasus : PMB UKDW dan PMB STIM AMIKOM Yogyakarta).

Sarjono, Haryadi dan Winda Julianita. . SPSS vs Lisrel, Sebuah Pengantar Aplikasi untuk Riset. Jakarta: Salemba Empat.

Setiawan, Budi. 2015. Teknik Praktis Analisis Data Penelitian Sosial \& Bisnis dengan SPSS. Yogyakarta: Andi Ofset

Suhendi dan Indra Sasangka. 2014. Pengantar Bisnis. Bandung: Alfabeta

Tjiptono, Fandi. 2004. Strategi Pemasaran, edisi kedua. Yogyakarta: Andi Ofset

Zimmerrer, Thomas W dan Scarborough, Norman M. 2002. Pengantar Kewirausahaan dan Manajemen Bisnis Kecil. Jakarta: Prenhallindo. , UU No. 25 Tahun 1992 Tentang Perkoperasian. 